\title{
Symbolika universum świątyni gotyckiej na podstawie wyników badań archeologicznych przy kościele św. Jakuba w Toruniu*
}

Natalia Stawarz

Toruń

Chrześcijaństwo od swych początków związane było z symbolizmem. Dogmaty, na których opierała się religia chrześcijańska, wymagały pewnej materializacji, dlatego symbol jako realny dowód świętości przejawia się na każdej płaszczyźnie wierzeniowej. Świątynia, która była domem Boga, była jednocześnie nośnikiem symbolu. W każdym okresie, w każdej religii, w każdym rodzaju budowli sakralnej symbol przemawiał językiem Boga. Symboliczne odzwierciedlenie świętości najlepiej uchwycił styl gotycki, który nie tylko składał się z odosobnionych metafor, ale cały był symbolem.

Badania nad sakralną architekturą gotycką prowadzone są od wielu lat. Świątynie gotyckie poddawane są analizie architektonicznej, historycznej, archeologicznej, jak i teologicznej. Warto jednak dołączyć do tych badań kwestię postrzegania symbolicznego, która łączy się z takimi dziedzinami nauki, jak religioznawstwo czy kulturoznawstwo. Charakterystyka symbolu i jego postrzeganie są niezbędnym narzędziem

${ }^{*}$ Publikacja jest fragmentem pracy magisterskiej pt. „Rola, funkcja i symbolika gotyckich budowli sakralnych na ziemi chełmińskiej na podstawie badań archeologicznych", napisanej w Instytucie Archeologii UMK w Toruniu na seminarium dr hab. Krystyny Sulkowskiej-Tuszyńskiej, prof. UMK. Podstawą tej pracy były wyniki badań z trzech obiektów sakralnych: przedstawionym poniżej kościele św. Jakuba - świątyni parafialnej Nowego Miasta Torunia, kościele św. Jana Chrzciciela i św. Jana Ewangelisty - świątyni parafialnej Starego Miasta Torunia - oraz w kościele Podwyższenia Krzyża Świętego w Przecznie. 
dla próby odtworzenia mentalności i religijności średniowiecznego społeczeństwa.

\section{Znaczenie symboliki universum}

Symbolika jest nieodłącznie związana ze świątynią chrześcijańską. Kościół wzniesiony z kamieni jest odzwierciedleniem Kościoła dusz, ciała mistycznego. Kamienie służące jako budulec są alegorią „kamieni żywych", jakimi są wierni. Świątynia na tym świecie ma przypominać niebiańskie Jeruzalem, które w przyszłym, nieśmiertelnym życiu będzie nagrodą dla dobrych chrześcijan ${ }^{1}$.

Symbolikę można postrzegać $\mathrm{w}$ wielu aspektach i koncepcjach, jednak w odniesieniu do średniowiecza najbardziej istotna była idea symboliki tradycyjnej. Człowiek współczesny postrzega świat jako zlepek zjawisk, gdy tymczasem dla człowieka żyjącego w zachodniej Europie do czasów Kartezjusza świat wydawał się organizmem harmonijnym i zhierarchizowanym, którego chrześcijańską formułę znajdujemy u Dionizego Areopagity, a ten z kolei odsyła nas do Platona. W koncepcji tradycyjnej w mniejszym stopniu bierze się pod uwagę zjawiska i siły materii, natomiast bardziej uwzględnia się wewnętrzną strukturę świata, jego duchową architektonikę wywodzącą się z metafizyki, przede wszystkim Platona, następnie kontynuowaną przez pierwszych Ojców Kościoła. W tym ostatnim wyobrażeniu świata, czyli kosmologii, quasi-duchowa jedność wszystkich części kosmosu pozwala odkryć paralele między poszczególnymi jego elementami, a następnie między owymi elementami oraz ich ontologicznym modelem, który znajduje się w Bogu i według którego Bóg je stworzył i urzeczywistnił $\mathrm{w}$ porządku przestrzenno-czasowym ${ }^{2}$. Jest to podstawowa definicja symboliki kosmologicznej. Rozwija się ona na dwóch hierarchicznych poziomach: symboliki części wobec całości wszechświata oraz - na planie wyższym - symboliki universum i jego części względem świata boskiego. Jej znaczenie najlepiej obrazują słowa świętego Bonawentury: „Każda rzecz w każdej ze swych właściwości ukazuje boską Mą-

\footnotetext{
${ }^{1}$ J. Hani, Symbolika świątyni chrześcijańskiej, Kraków 1994, s. 14.
}

${ }^{2}$ Ibid., s. 15-16. 
drość i ten, kto pozna te właściwości bytów, zobaczy Ją jasno. Wszystkie stworzenia świata widzialnego prowadzą nas do Boga: bo są one cieniem, wizerunkiem, śladem, obrazem, przedstawieniem Przedwiecznego, Mądrości, najwyższej Zasady wszystkiego; są obrazem Źródła i Światła, wiecznej Pełni, suwerennego Archetypu: są znakami danymi nam przez samego Boga" ". Symbole zawarte w gotyckich budowlach sakralnych są niczym innym jak odtworzeniem doskonałości wszechświata. Człowiek wierzący potrafił dostrzec Stwórcę, creatora w całym dziele Stworzenia.

Wszystko, co człowiek pojmuje zmysłami, może go informować o rzeczywistości nadzmysłowej i przekształcić się w symbol. Symbole należą do form obcowania z Bogiem, mają za zadanie oddawać cześć istocie boskiej, jak i wspierać i uświęcać ludzkie życie, doświadczać błogosławieństw i łask oraz chronić przed szkodliwymi mocami ${ }^{4}$.

Rozważając symbolikę universum, należy powrócić do średniowiecznej filozofii chrześcijańskiej i zadać fundamentalne pytanie: czy Bóg istnieje? Rozważania te przeprowadził Tomasz z Akwinu. Ukazał on Boga jako architekta, który kreuje świat ze swą mądrością wedle miary, liczby i wagi. $\mathrm{W}$ swych rozmyślaniach Tomasz z Akwinu podaje całe istnienie w wątpliwość i dopiero wtedy odpowiada na nurtujące pytanie: „Istnienie Boga można udowodnić na pięciu drogach. Pierwsza i bardziej przejrzysta wychodzi ze zjawisk ruchu, którego istnienie stwierdzamy na tym świecie za pomocą zmysłów. Ale wszystko, co się porusza, zostało pobudzone do ruchu przez coś innego [...] Ale w szeregu tych czynników powodujących ruch (czy zmianę) nie można iść do nieskończoności, bo wówczas nie byłoby pierwszej przyczyny ruchu [...] Tak więc, trzeba przyjąć istnienie pierwszego źródła (czy zmianę), będącego bytem nieporuszalnym przez cokolwiek innego (czyli bezwzględnie niezmiennym)" ". Ruch opisany przez świętego Tomasza jest analogią życia. Tak jak Bóg tworzył nasz świat, tak śre-

\footnotetext{
${ }^{3}$ Ibid., s. 16.

${ }^{4}$ M. Lurker, Przestanie symboli w mitach, kulturach i religiach, Kraków 1994, s. 70.

${ }^{5}$ Święty Tomasz z Akwinu. Skrót zarysu teologii, oprac. F.W. Bednarski OP, 2000; J. Maier, Zachować i odnowić wiarę. Rozwinięte i późne średniowiecze, 1000-1499, [w:] Kronika chrześcijańska, pod red. B. Beier, Warszawa 1997, s. 173.
} 
dniowieczni architekci tworzyli świątynie gotyckie, które miały oddawać cześć i chwałę Wszechmogącemu Stwórcy.

Każda budowla sakralna jest kosmiczna, gdyż jest obrazem świata. Obraz, który reprezentuje świątynia, jest w pierwszej kolejności „realistyczny". Wchodząc do świątyni człowiek dostrzega na murach i kolumnach niebo i ziemię, zwierzęta i rośliny, prace ludzkie i rozmaite stany społeczne, historię naturalną i historię świętą. Jest to jednak czysto zewnętrzny, doczesny aspekt, właściwy tylko wielkim budowlom. Według św. Piotra Damiana świątynia nie jest tylko „realistycznym" obrazem świata, lecz przede wszystkim jest obrazem „strukturalnym" w tym sensie, że odtwarza ona strukturę wewnętrzną i matematyczną universum. W tym tkwi jej wysublimowane piękno ${ }^{6}$. Myśląc o universum należy pamiętać, że nie dotyczy ono tylko tego, co znajduje się ponad atmosferą ziemską. $\mathrm{Z}$ całą pewnością owo pojęcie wiąże się z Królestwem Niebieskim, ale jej głównym, powtarzającym się elementem jest dzieło Stworzenia. Natura, która otaczała człowieka od czasów najdawniejszych, była postrzegana jako dzieło doskonałe. Człowiek, budując gotyckie katedry, chciał w ten sposób oddać cześć doskonałości stworzonej przez Boga. Chciał oddać hołd światu. Każdy element kościoła, poddając się symbolice, tworzy jedną, perfekcyjną całość. Nie ma świątyni gotyckiej, która byłaby obojętna wobec symbolizmu universum.

\section{Zarys historii świątyni św. Jakuba Apostoła w Toruniu}

Kościół św. Jakuba Apostoła był świątynią parafialną Nowego Miasta Torunia. Jego miejsce w urbanistyce Nowego Torunia wyznaczono w północno-wschodnim bloku przyrynkowym. Rok 1309 określa się jako początek budowy kościoła: to w tym czasie biskup chełmiński Herman położył kamień węgielny pod budowę prezbiterium świątyni. Datę tę potwierdza inskrypcja obiegająca wnętrze chóru? ${ }^{7}$. Akta wizytacyjne pochodzące z XVIII w. podają informację, że parafia

\footnotetext{
${ }^{6}$ J. Hani, op. cit., s. 27.

${ }^{7}$ L. Krantz-Domasłowska, J. Domasłowski, Kościół św. Jakuba w Toruniu, Toruń 2001, s. 9
} 
została utworzona w 1304 r. ${ }^{8}$ Budowę kościoła ukończono około 1340 r., co poświadcza dokument wielkiego mistrza krzyżackiego Ludolfa Königa, w którym potwierdził nadanie kościoła zakonowi żeńskiemu, dokonane przez jego poprzednika Teodoryka von Altenburg (13351341) ${ }^{9}$. Część badaczy przypuszcza, że nadanie dotyczyło klasztoru cysterek, a część, że benedyktynek. Oba zakony funkcjonowały w mieście, jednak źródeł, które mogą przybliżyć ich historie, jest niewiele. Potwierdzonym dowodem na obecność benedyktynek w Toruniu jest fundacja klasztoru przez wielkiego mistrza krzyżackiego Karola z Trewiru (1311 r.). Konwent sióstr miał powstać przy szpitalnym kościele Świętego Ducha nad Wisłą. Szesnastowieczny przekaz wyznaczał datę powstania zakonu cysterek na rok 1263. Informacje na temat obu klasztorów są ograniczone i trudno ustalić, które ze zgromadzeń otrzymało fundację w świątyni św. Jakuba, dlatego przyjęła się nazwa powszechnie stosowana $\mathrm{w}$ literaturze - cysterki-benedyktynki ${ }^{10}$. Zakonnice utraciły kościół św. Jakuba w roku 1557, gdyż został on przejęty przez ewangelików. Powróciły w 1667 r. i opiekowały się nim aż do roku 1833 , kiedy to władze pruskie dokonały kasaty zgromadzenia ${ }^{11}$.

Kościół wielokrotnie płonął. Jeden z udokumentowanych pożarów wybuchł w roku 1455, kiedy to podczas krzyżackiego oblężenia spłonąć miała niemal cała połowa Nowego Miasta, w tym wieża kościoła parafialnego wraz z dzwonami ${ }^{12}$.

\section{Opis bryły świątyni}

Zasadniczy projekt bryły kościoła św. Jakuba Apostoła można odczytać w istniejącej do dziś budowli. Pierwszym członem był chór,

\footnotetext{
${ }^{8}$ L. Krantz-Domasłowska, Dwa miasta - dwa kościoły, [w:] Dzieje i skarby kościoła świętojańskiego w Toruniu, pod red. K. Kluczwajd, M. Woźniaka, Toruń 2002, s. 199.

${ }^{9}$ Ibid., s. 202.

${ }^{10}$ A. Cicha, Klasztor cysterek-benedyktynek przy kościele pw. św. Jakuba w Toruniu w świetle źródet ikonograficznych i archeologicznych, [w:] Dzieje i skarby kościota świętojakubskiego w Toruniu, pod red. K. Kluczwajd, Torun 2010, s. 141-142, L. Krantz-Domasłowska, J. Domasłowski, op. cit., s. 10-11.

${ }^{11}$ A. Cicha, op. cit., s. 143.

${ }^{12}$ L. Krantz-Domasłowska, J. Domasłowski, op. cit., s. 12.
} 
który został ukończony i udostępniony do użytku około $1320 \mathrm{r}$. Jest to długie, smukłe wnętrze na planie prostokąta, z wydzielonymi czterema prostokątnymi przęsłami. Od strony północnej przylegała do niego niewielka, trójprzęsłowa zakrystia. W południowo-wschodnim narożu „wpisana" została wieżyczka schodowa. We wnętrzu chóru dominuje szereg wąskich, ostrołucznych okien, osadzonych w głębokich ościeżach. Powierzchnia ścian w świątyni została wypełniona otworami okiennymi, co jest szczególnie widoczne we wschodnim zamknięciu, wypełnionym triadą okien. Rytm pionów wzbogacono cylindrycznymi służkami, stanowiącymi łącznik między posadzką i żebrami sklepienia. Kształt przestrzeni zarysowany został poprzez sklepienia o rysunku czteroramiennej gwiazdy oraz sklepienie pseudopoligonalne w pogłębionym przęśle wschodnim. Takie rozwiązanie architektoniczne nadawało efekt iluzji wielobocznego zamknięcia chóru ${ }^{13}$. Od zachodu wzniesiono smukłą i wąską wieżę o szerokości nawy środkowej, subtelnie wtopioną w bryłę. Właściwa część nawowa tworzy prostokąt, nieznacznie tylko dłuższy od chóru, w którym wyodrębniają się trzy kwadratowe przęsła nawy środkowej oraz przęsła w kształcie wąskich prostokątów w nawach bocznych. Przestrzeń korpusu została widocznie zhierarchizowana. Nad niskimi arkadami otwierającymi się do naw bocznych wznosiła się lita ściana, w której osadzono okna w głębokich, ostrołucznych wnękach. Wnęki te skomunikowane były ze sobą otworami w grubości ściany i tworzyły emporowy ganek. Wertykalne podziały stanowiły linearny schemat systemu baldachimowego, gdzie żebra sklepienne łączyły się z posadzką za pomocą służek i przypór ${ }^{14}$.

Na zewnątrz kościoła zwraca uwagę dekoracyjne opracowanie elewacji chóru. Tworzą ją ozdobne zwieńczenia przypór $\mathrm{w}$ formie sterczyn $\mathrm{z}$ wimpergami i żabkami, dwubarwny fryz inskrypcyjny oraz szczyt wschodni, gdzie wykorzystano efekty malowanych blend, czerwieni ceglanego tła wzbogaconego glazurowaną cegłą. Korpus nawowy wyróżniał się widocznym systemem konstrukcyjnym opartym na systemie przypór i łuków odporowych, zakończonych dekoracyjnymi

\footnotetext{
${ }^{13}$ L. Krantz-Domasłowska, op. cit., s. 202.

${ }^{14}$ A. Błażejewska, E. Pilecka, Sztuka średniowiecza, [w:] Dzieje sztuki Torunia, pod red. A. Błażejewskiej, Toruń 2009, s. 65; L. Krantz-Domasłowska, op. cit., s. 204.
} 
sterczynami wychodzącymi poza linię dachu. Wieża zachodnia, która wyrastała z korpusu, dopełniała monumentalnym wyglądem trójczłonową bryłę kościoła ${ }^{15}$. Bez wątpienia świątynia świętojakubska wyróżniała się na tle innych obiektów architektonicznych wznoszonych na ziemi chełmińskiej i powstających według swoistego szablonu: zwartych, solidnych, praktycznych, o surowej monumentalności ${ }^{16}$.

\section{Analiza archeologiczna, funkcjonalna i symboliczna}

Badania archeologiczno-architektoniczne w obrębie kościoła św. Jakuba Apostoła i funkcjonującego przy nim klasztoru prowadzone były w latach 2008-2015. W ciągu kilku lat badań na terenie przykościelnym zostało założonych łącznie 14 wykopów (ryc. 1), w obrębie których odsłonięto historię świątyni - to z kolei pozwala na zrozumienie jej funkcji i symboliki ${ }^{17}$.

Badaniom archeologiczno-architektonicznym przy kościele św. Jakuba Apostoła przyświecało kilka celów. Jednym z nich było rozpoznanie stratyfikacji przy murach świątyni. Istotnymi kwestiami, które zostały poruszone podczas badań archeologicznych, były próby określenia najstarszych śladów osadnictwa w obrębie nawarstwień. Badania przy prezbiterium miały również na celu ustalenie ewentualnej obecności śladów starszego kościoła z XIII w. Ponieważ przy kościele znajdował się cmentarz parafialny, kolejnym zadaniem ekspedycji było uzyskanie danych stratyfikacyjnych oraz rozpoznanie kultury funeralnej mieszczan nowomiejskich na podstawie artefaktów znalezionych w obrębie pochówków. Jednym z głównych celów ekspedycji było odkrywanie historii i zabudowy klasztoru cysterek-benedyktynek, który połączony był z kościołem za sprawą korytarza ${ }^{18}$.

\footnotetext{
${ }^{15}$ L. Krantz-Domasłowska, op. cit., s. 204.

${ }^{16}$ A. Błażejewska, E. Pilecka, op. cit., s. 69.

${ }^{17}$ Kierownikiem i koordynatorem prac wykopaliskowych w każdym sezonie badawczym była dr hab. Krystyna Sulkowska-Tuszyńska, prof. UMK. Prace zostały przeprowadzone przez Zakład Archeologii Architektury Instytutu Archeologii UMK w ramach ćwiczeń terenowych dla studentów.

${ }^{18}$ K. Sulkowska-Tuszyńska: Badania archeologiczno-architektoniczne przy kościele św. Jakuba Apostoła w Toruniu 2008, Toruń 2008, s. 6; Toruń - Nowe Miasto 2010. Badania archeologiczno-architektoniczne przy kościele św. Jakuba Apostoła w Toru-
} 


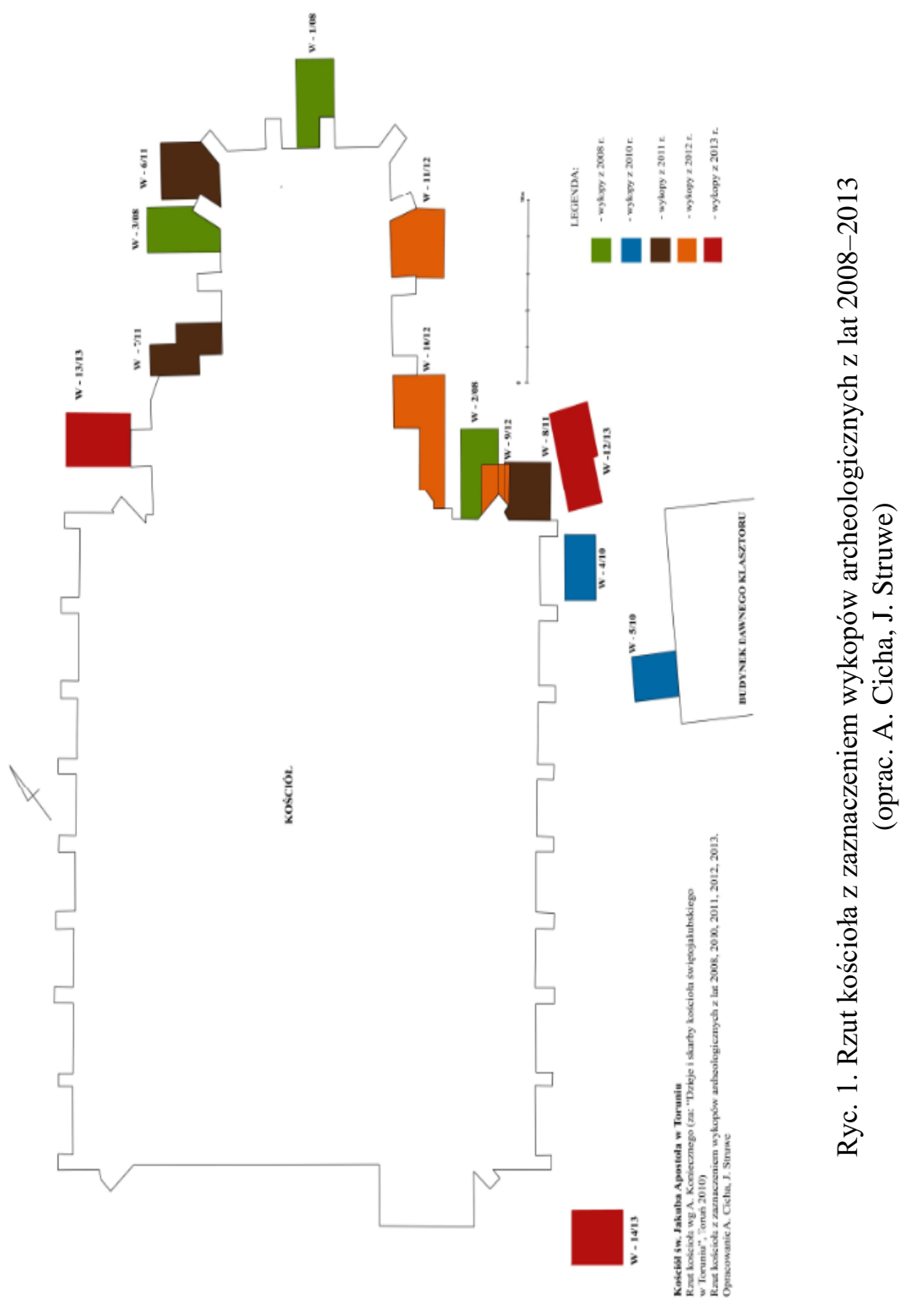




\section{Gotlandzka misa chrzcielna}

W roku 2008 rozpoczęła się pierwsza ekspedycja w obrębie kościoła św. Jakuba Apostoła. Założono trzy wykopy (W-1/08, W-2/08 i W3/08) na styku architektury, wokół prezbiterium. Ustalono, że wokół prezbiterium kościoła św. Jakuba istniał cmentarz, który funkcjonował nieprzerwanie od XIII do XIX w.; odsłonięto niewielkie części czterech fundamentów, w tym: kamienny fundament z XIII w., znajdujący się pod obecnym kościołem (W-3/08), oraz fundament kamienno-ceglany wydatowany najwcześniej na XIV w., oparty o jedną ze wschodnich skarp (W-1/08). Najstarszym i najcenniejszym zabytkiem ruchomym była kamienna misa $(\mathrm{W}-2 / 08)^{19}$.

Fragment kamiennej misy (IZW1240/08) (ryc. 2) został odnaleziony przed bocznym portalem południowej ściany prezbiterium, dwa metry od wschodniej ściany nawy południowej, w wykopie drugim (W2/08). W warstwie poniżej (III) zarejestrowano poziom użytkowy przed portalem. Do najmłodszych artefaktów należały fragmenty naczyń kamionkowych używanych jeszcze w XIX w. Warstwę drugą można datować na drugą połowę XIX w. lub nawet na przełom między XIX i XX w. W tym czasie prawdopodobnie został porzucony fragment kamiennej misy ${ }^{20}$.

niu (2 kampania wykopaliskowa), Toruń 2011, s. 1; Toruń - Nowe Miasto 2012. Badania archeologiczno-architektoniczne przy kościele św. Jakuba Apostoła w Toruniu (4 kampania wykopaliskowa), Torun 2013, s. 2; Toruń - Nowe Miasto 2013. Badania archeologiczno-architektoniczne przy kościele św. Jakuba Apostoła w Toruniu $(5 \mathrm{kam}$ pania wykopaliskowa), Toruń 2014, s. 4; Apud terram ante ecclesiam. Nieopisane karty kościoła i parafii św. Jakuba w Toruniu, Pomerania Antiqua, t. XXIII, Gdańsk 2010, s. 249-273; Primum non nocere! O archeologicznych badaniach wokół toruńskiego kościoła św. Jakuba, [w:] Stare i nowe dziedzictwo Torunia, red. A. Raczkowski, Toruń 2013, s. 58-73.

${ }^{19}$ K. Sulkowska-Tuszyńska, Badania archeologiczno-architektoniczne przy kościele św. Jakuba Apostoła w Toruniu 2008, s. 2.

${ }^{20}$ K. Sulkowska-Tuszyńska, Kamienna misa chrzcielna odkryta przy kościele św. Jakuba w Toruniu, Slavia Antiqua, t. LIII, 2012, s. 190. 


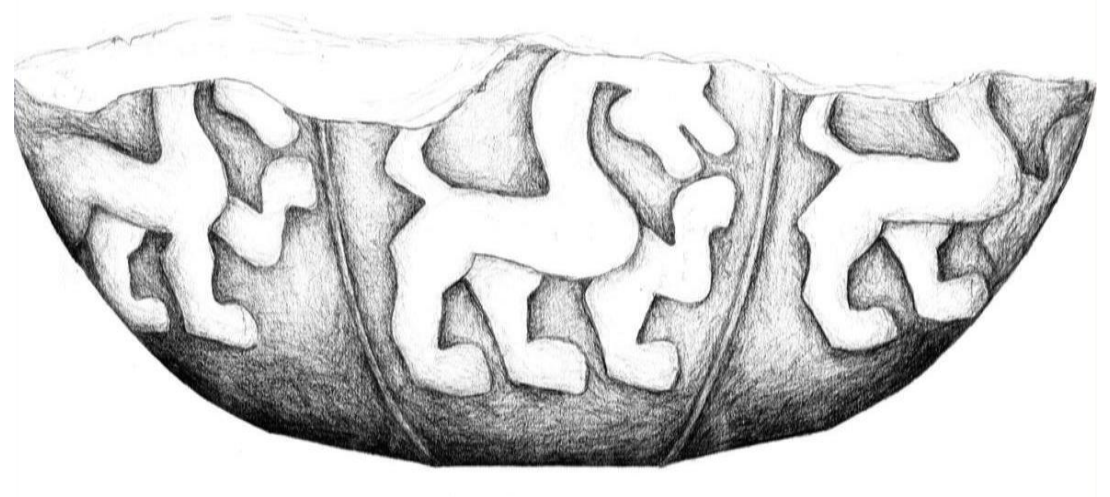

Ryc. 2. Kamienna misa z kościoła św. Jakuba Apostoła

(K. Sulkowska-Tuszyńska, Kamienna misa chrzcielna)

Kamienny obiekt interpretowany jako misa chrzcielna zachował się w około $2 / 5$ całości. Po wewnętrznej stronie przypominał półkulę, natomiast strona zewnętrzna niegdyś stanowiła ośmiobok ${ }^{21}$.

Zarówno ośmiobok, jak i kula, swym kształtem miały uosabiać chwałę Boga. Obie kompozycje, zarówno kulista, jak i ośmioboczna przyjęły się $\mathrm{w}$ tradycji chrześcijańskiej jako popularna forma chrzcielnicy. Koło reprezentuje ciągłość i doskonałość, a ponadto symbolizuje niebo, czyli chrzest, który oczyszcza człowieka z grzechów i daje perspektywę życia wiecznego ${ }^{22}$. Ośmiokąt jest wyobrażeniem ósmego dnia, który nastąpi po nieskończonym na pozór cyklu tygodnia, wraz z nadejściem Sądu Ostatecznego. Tak więc chrzcielnica ma przypominać o naszej wieczności w raju. Ósemkę pojmowano wieloznacznie i symbolicznie. Uważano ją za jedną z sakralnych liczb chrześcijaństwa. Osiem osób znajdowało się w Arce Noego, którą przyjęto za symbol

\footnotetext{
${ }^{21}$ Ibid., s. 190.

${ }^{22}$ R. Stemp, Sekretny język kościołów i katedr: rozszyfrowywanie świętej symboliki sakralnych budowli chrześcijaństwa, Warszawa 2012, s. 44.
} 
chrztu i Kościoła. Według świętego Karola Boromeusza ośmiobok był najbardziej stosowną formą dla chrzcielnicy, gdyż stanowił on tajemniczy symbol doskonałości i życia wiecznego. Raj osiągalny jest po siedmiu niebach planetarnych jako ósme niebo - symbol wieczności. Siedem kolorów tęczy zlewało się w jeden - biały, który stanowi ich jedność i zasadę, jak również jest kolorem chrztu ${ }^{23}$. Gwiazda ośmioramienna albo róża wiatrów symbolizowały tchnienie Ducha nad pierwotnymi wodami. To stella maris, gwiazda morza, znak Ducha nad wodami, której formą zwierzęcą była ośmiornica, we wczesnym chrześcijaństwie przyjęta jako symbol duszy odrodzonej w wodzie chrztu ${ }^{24}$. Chrzcielnice również bywają zdobione obrazami chrztu Chrystusa, mogą też przedstawiać sceny z życia Jana Chrzciciela, a także inne biblijne relacje związane $\mathrm{z}$ tym obrzędem, zwłaszcza scenę zmartwychwstania. Ośmioboczne chrzcielnice mogą ukazywać siedem sakramentów, przy czym chrzest jest pierwszym z nich. Ósma ściana przedstawiała jakiś ogólny motyw, na przykład anioła ${ }^{25}$.

Niestety, przy misie nie zachowały się brzegi oraz trzy ścianki. Maksymalna wysokość czaszy wynosi $24 \mathrm{~cm}$, pierwotnie jej wysokość mogła osiągać $35 \mathrm{~cm}$. Średnica zewnętrzna brzegu misy wynosi $62 \mathrm{~cm}$, wewnętrzna $40 \mathrm{~cm}$, a grubość ścianek około 7-10,5 cm. Półkulista forma, która tworzy wnętrze misy, została starannie wygładzona - tu także widać ciemne, poziome pasy zabrudzeń. Prawdopodobnie jest to ślad po metalowej misie, którą wkładano do wnętrza. Dno po stronie zewnętrznej jest płaskie - jest więc niemal pewne, że misa w przeszłości pełniła swoją funkcję jako chrzcielnica ${ }^{26}$.

Na płaskich i wygładzonych powierzchniach ścian, mimo ich zabrudzenia, już po odkryciu można było stwierdzić wypukły ornament (wypukłość reliefu wynosiła około 3-4 mm ponad powierzchnię tła). $\mathrm{Na}$ zachowanych częściowo płaszczyznach ukazano po jednym kroczącym lwie. Na jednej lew jest niemal cały, na drugiej jego tylna połowa, na trzeciej przednia, większa partia. Co do czwartej płaszczy-

\footnotetext{
${ }^{23}$ J. Hani, op. cit., s. 82.

${ }^{24}$ Ibid.

${ }^{25}$ R. Stemp, op. cit., s. 45.

${ }^{26}$ K. Sulkowska-Tuszyńska, Kamienna misa chrzcielna, s. 190.
} 
zny, zachowanej jedynie w partii dolnej, istnieje przypuszczenie, że jedna wypukłość to łapa zwierzęcia. Po oczyszczeniu obiektu można stwierdzić, że zachowało się sześć z ośmiu ścianek misy. Na czterech z nich pozostały bardziej lub mniej wyraźne ślady reliefu. Jedna ścianka była go pozbawiona. Jej powierzchnia nie została wybrana, tak jak pozostałe, i nosi wyraźne ślady ostrego dłuta. Inna ścianka ma tak małą powierzchnię, że nie można ustalić, czy również została ozdobiona ${ }^{27}$. Interpretując relief otaczający misę, należy odwołać się do sakramentu chrztu. Inicjacja, w której człowiek przechodzi na kolejny etap - odradza się, wiąże się również ze zjawiskiem psychomachii, kiedy to dobro i zło po raz pierwszy podejmują walkę o duszę. Lwy znajdujące się na misie były nie tylko elementami dekoracyjnymi, ale także dodatkowymi apotropaionami w walce ze złem. Analogiczny wizerunek znajduje się na brązowej czaszy chrzcielnicy z kościoła Świętych Janów. Interesującym zagadnieniem jest brak reliefu na jednej z płaszczyzn. Być może kiedyś znajdował się w tym miejscu jakiś element dekoracji, który został usunięty intencjonalnie. Istnieje możliwość, że na tej płaszczyźnie misa opierała się o ścianę. Brak reliefu mógł zapewniać jej stabilność. Inną opcją wyjaśniającą brak reliefu jest porównanie każdej płaszczyzny z poszczególnym dniem. Ósma płaszczyzna mogła być interpretowana jako ósmy dzień, który oznaczał wieczność. Może artysta zinterpretował pusty fragment jako miejsce, w którym nie ma potrzeby ochrony, bo tę daje Bóg.

Kamienne misy wykorzystywane w przestrzeni sakralnej jako chrzcielnice lub kropielnice znane są z wielu średniowiecznych świątyń. Jedną z popularniejszych form była chrzcielnica w kształcie kielicha o półkulistej czaszy, podtrzymywanej na trzonie z szeroką, stabilną stopką. Ten typ chrzcielnic dominował $\mathrm{w}$ późnym średniowieczu i nawiązywał do skojarzeń z Eucharystią i chrztem. Znano tę formę zarówno na ziemiach polskich, jak i w wielu miejscach w Europie. Przedstawienia ikonograficzne - drzeworyty, kwatery witraży, miniatury - potwierdzały jej popularność jako chrzcielnicy ${ }^{28}$. Jednym z miejsc, gdzie taki „,chrzcielny kielich” był popularny, była Gotlandia, formę tę

\footnotetext{
${ }^{27}$ Ibid., s.190-191.

${ }^{28}$ Ibid., s. 191-192.
} 
produkowano tam między XII i XIV w. Tradycyjne gotlandzkie dwunastowieczne chrzcielnice mają charakterystyczną, masywną podstawę. Na górnym wałku pod czaszą ozdabiano je pełnoplastycznymi głowami ludzkimi lub zwierzęcymi ${ }^{29}$.

Analogii do misy chrzcielnej z kościoła św. Jakuba należy szukać w kościele św. Mikołaja w Grudziądzu, druga pochodzi z Lubiany w województwie zachodniopomorskim, natomiast trzecia $\mathrm{z}$ Wilamowa niedaleko Łęczycy. Wszystkie zostały zgrupowane jako analogiczne ze względu na cechy wspólne - kształt półkuli oraz dominujący motyw zdobniczy, jakim była zoomorficzna dekoracja w postaci lwów kroczących dookoła misy, $\mathrm{z}$ podniesionymi do góry ogonami ${ }^{30}$. Według badań Jadwigi Kuczyńskiej gotlandzki typ romańskiej chrzcielnicy skupia się wokół Pomorza Zachodniego, a nieliczne jej przykłady można spotkać w obrębie państwa zakonu krzyżackiego. Prezentują się jako formy kielichowe zdobione arkadkami i przedstawieniami fantastycznych zwierząt. Autorka uważa, że były to dzieła warsztatów gotlandzkich eksportowane do krajów bałtyckich, ale ich zasięg na terenach polskich nie był szeroki ${ }^{31}$. Z Chełmna pochodzi jeszcze jedna misa, która swym kształtem i zdobieniami przypomina chrzcielnicę jakubową. Chrzcielnica została wykonana $\mathrm{z}$ wapienia, składała się $\mathrm{z}$ wielobocznej czaszy ustawionej na nowej podstawie. Boki czaszy pokryte zostały późnoromańskimi płaskorzeźbami o motywach zoomorficznych, z wyobrażeniami gryfa, smoka, dwugłowego orła i konia. Została importowana $\mathrm{z}$ Gotlandii. Jej wiek należy wiązać z początkami funkcjonowania kościoła ${ }^{32}$. Podobnie jak w przypadku motywu dekoracyjnego chrzcielnicy z kościoła św. Jakuba, zwierzęta, które pojawily się na chełmińskiej misie chrzcielnej, mają symboliczne, ochronne znaczenie.

Misa znaleziona przy kościele św. Jakuba Apostoła w Toruniu została poddana badaniom w Pracowni Petrograficznej Politechniki Wro-

\footnotetext{
${ }^{29}$ Ibid., s. 192.

${ }^{30}$ J. Kuczyńska, Średniowieczne chrzcielnice kamienne w Polsce. Katalog, Lublin 1984, s. 51-54; K. Sulkowska-Tuszyńska, Kamienna misa chrzcielna, s. 192-193.

${ }^{31}$ J. Kuczyńska, op. cit., s. 11; K. Sulkowska-Tuszyńska, Kamienna misa chrzcielna, s. 193.

${ }^{32}$ L. Krantz-Domasłowska, J. Domasłowski, Kościót farny w Chetmnie, Toruń 1991, s. 41.
} 
cławskiej. Próby wykazały, że reprezentuje ona naturalną, osadową skałę, która składa się głównie z kryształków węglanów. Niestety, wydatowanie misy jest niemożliwe. Wojciech Bratz uważa, że źródłem skały mogły być sylurskie wapienie wydobywane na Gotlandii ${ }^{33}$. W laboratorium Naukowo-Badawczym Polskich Pracowni Konserwacji Zabytków SA w Toruniu przeprowadzono badania nad pigmentem, którym teoretycznie mogła być przyozdobiona misa. Wyniki wykazały, że na powierzchni jasnoszarego, nierównomiernie wybarwionego kamienia zachowały się ślady białej lub kremowej zaprawy lub cegły, a na samej powierzchni misy znajdowała się cienka biała warstwa malarska dobrze związana z podłożem. Warstwa została naniesiona, aby zakryć pierwotny brud ${ }^{34}$. W Pracowni Dokumentacji i Konserwacji Instytutu Archeologii Uniwersytetu Mikołaja Kopernika w Toruniu, po pobraniu próbek, zachowane partie misy oczyszczono z wtórnych nawarstwień za pomocą pary wodnej, przez ich spulchnienie, a następnie mechaniczne usuwanie skalpelami lub szczotkami z syntetycznym włosiem. Podczas konserwacji zauważono jedno znaczne pęknięcie czaszy ${ }^{35}$.

Po wstępnych ustaleniach można stwierdzić, że misa została przywieziona do Torunia prawdopodobnie $\mathrm{z}$ Gotlandii, na zamówienie któregoś z mistrzów krzyżackich, najpóźniej w latach dwudziestych XIV w., kiedy to kończono budowę prezbiterium św. Jakuba ${ }^{36}$.

Na podstawie uzyskanych informacji można podjąć próbę zrekonstruowania dziejów chrzcielnicy w przestrzeni świątynnej. Kamienna misa mogła być elementem wyposażenia kościoła. Na początku prawdopodobnie znajdowała się $\mathrm{w}$ zachodniej partii prezbiterium. Około drugiej połowy XV w., gdy wokół naw zakończono budowę wieńca kaplic, być może w zachodniej części nawy południowej, przy trzech stopniach ustawiono kamienną chrzcielnicę. Po jakimś czasie wymieniono ją na chrzcielnicę brązową. Trudno jednak zbudować właściwy obraz bez potwierdzenia tych przypuszczeń badaniami archeologicznymi. W okresie ewangelickim chrzcielnica znajdowała się prawdopo-

\footnotetext{
${ }^{33}$ K. Sulkowska-Tuszyńska, Kamienna misa chrzcielna, s. 197-198.

${ }^{34}$ Ibid., s. 198-199.

${ }^{35}$ Ibid., s. 199.

${ }^{36}$ Ibid., s. 199-200.
} 
dobnie w prezbiterium. Od roku 1667, gdy powróciły siostry benedyktynki, zgodnie z regułą i w obawie przed zimnem zbudowały one łącznik między klasztorem i kościołem. Prawdopodobnie właśnie w nim umieszczono chrzcielnicę. Taki stan trwał do 1830-1831 r., kiedy to władze pruskie postanowiły zlikwidować klasztor, a wraz z nim całe uposażenie konwentu. Istniała też druga możliwość. Po pożarze kościoła w XV w. misa została uszkodzona, po czym wmurowano ją jako zwykły kamień do jakiegoś fundamentu. W czasie rozbiórki przeprowadzonej na przełomie XIX i XX w. wyrzucono ją wraz z dachówkami i cegłami ${ }^{37}$.

Misa chrzcielna to ważny zabytek przy rozpatrywaniu symboliki universum. Chrzest był pierwszym krokiem człowieka w drodze do nieśmiertelności w raju. $\mathrm{W}$ tradycyjnej symbolice każdy zbiornik na wodę rytualną jest pamiątką pierwotnego oceanu, „wody” z Genesis, nad którą unosił się Duch Boży zanim rozpoczął się akt stworzenia. Symbolika wód jest w tym przypadku wynikiem intuicyjnego pojmowania kosmosu jako jedności oraz człowieka jako specyficznego sposobu egzystencji, który realizuje się w „historii”. To odniesienie nadaje chrzcielnicy i kropielnicy moc dokonywania odrodzenia i stwarzania na nowo ${ }^{38}$. Chrzest $\mathrm{w}$ tradycji chrześcijańskiej był od początku równoznaczny z inicjacją. Wprowadzał nawróconego do nowej wspólnoty religijnej i czynił go godnym życia wiecznego. Chrzest uświęcał wiernego i radykalnie modyfikował jego porządek egzystencjalny. Sakrament ten włączał go do wspólnoty wybrańców ${ }^{39}$. Głównym celem chrztu było zbawienie duszy i wymazanie grzechów. Stał się on również narzędziem odrodzenia duchowego, gdyż zanurzenie w wodzie chrzcielnej odpowiada pogrzebaniu Chrystusa. Symbolicznie człowiek umiera poprzez zanurzenie, ale odradza się odnowiony i oczyszczony, podobnie jak Chrystus zmartwychwstały z grobu ${ }^{40}$. Woda była symbolem oczyszczenia, zatem chrzest zmywał grzech pierworodny i dawał

\footnotetext{
${ }^{37}$ Ibid., s. 202-203.

${ }^{38}$ M. Eliade, Traktat o historii religii, Warszawa 2009, s. 208; J. Hani, op. cit., s. 82.

${ }^{39}$ M. Eliade, Inicjacje, obrzędy, stowarzyszenia tajemne: narodziny mistyczne, Kraków 1997, s. 167-168.

${ }^{40}$ M. Eliade, Traktat, s. 207.
} 
szansę nowym wiernym na dostąpienie bram raju. Symbolika była jasnym przesłaniem o zwycięstwie dobra nad złem i przesłaniem o miłosierdziu bożym.

\section{Prezbiterium}

Istotą całej świątyni jest prezbiterium wraz z ołtarzem, gdzie symbolicznie przebywa Bóg. Ważne jest, aby bliżej poznać tę najświętszą przestrzeń, zwłaszcza w kontekście kościoła św. Jakuba w Toruniu. Przełomową publikacją na temat kościołów gotyckich na ziemi chełmińskiej była praca Teresy Mroczko z 1980 r. Autorka przedstawiła w niej dociekania nad architekturą kościoła św. Jakuba i szczegółowo scharakteryzowała bazylikowy układ. Wykazała, że kościół nie stanowił budowli jednolitej. Świątynia została zrealizowana konsekwentnie według wytyczonego planu, a w trakcie budowy wprowadzono liczne modyfikacje ${ }^{41}$. Rok po opublikowaniu studiów Teresy Mroczko pojawiła się synteza zmarłego w roku 1953 Ottona Freymutha poświęcona szczegółowym rozważaniom na temat historii i etapów budowy nowomiejskiego kościoła św. Jakuba. Wiele wniosków obojga badaczy, które uformowały się niezależnie od siebie, jest bardzo zbliżonych. Niektóre są możliwe do weryfikacji na obecnym etapie badań archeologicznych ${ }^{42}$. Otton Freymuth podał w wątpliwość fakt, że kościół od samego początku miał być $\mathrm{z}$ założenia bazyliką, i zadał pytanie na temat faktycznej datacji początków budowli. Krytykował dotychczasowe twierdzenia opierane na inskrypcji znajdującej się w prezbiterium, która odnosi się do początku jego budowy w 1309 r., a nie całej świątyni $^{43}$. Freymuth sugerował, że świątynia została wzniesiona przez co

${ }^{41}$ T. Mroczko, Architektura gotycka na ziemi chetmińskiej, Warszawa 1980 K. Sulkowska-Tuszyńska, Prezbiterium kościoła św. Jakuba po badaniach archeologiczno-architektonicznych. Nowa historia Nowego Miasta Torunia?, [w:] Nowe Miasto Toruń. 750 lat od lokacji, pod red. K. Mikulskiego, P. Olińskiego, W. Rozynkowskiego, Toruń 2014, s. 16.

${ }^{42}$ Ibid., s. 17.

${ }^{43}$ Ibid., s. $17-18$ 
najmniej dwóch mistrzów, którzy charakteryzowali się odmiennymi formami wyrazu. Starsze projekty znajdowały się w nawach ${ }^{44}$.

Po pięciu sezonach badawczych prowadzonych przy kościele św. Jakuba Apostoła Krystyna Sulkowska-Tuszyńska wykazała, że prezbiterium świątyni (ryc. 3), budowane od 1309 r. i zachowane do dziś, jest drugim prezbiterium w tym miejscu. Pierwsza forma (prezbiterium I) była murowana, a nie drewniana, jak przypuszczano. Znajdowała się dokładnie w tym samym miejscu i na tych samych fundamentach co prezbiterium II. Kamienne jednorodne fundamenty położono w jednej akcji budowlanej. W kwestii jednorodnego fundamentu pod prezbiteriami istnieją dwie opcje - albo zmiana koncepcji w tej samej budowie, albo dwie oddzielne fazy budowlane realizowane w znacznym odstępie czasu. Drugi wariant jest bardziej prawdopodobny. Za odmienną koncepcją architektoniczną pierwszego kościoła przemawia wielki fundament po południowej stronie, nieodpowiadający przyporze i zbędny przed bocznym portalem. Bogaty profil glebowy również świadczył o zasadniczych zmianach przy omawianych obiektach architektury. W tym przypadku pomiędzy nowożytną posadzką (2. połowa XVII w.) a koroną fundamentu narosło aż 6 jednostek - poziomów użytkowych i warstw budowlanych. Na fundamencie zachowała się warstwa miału ceglanego o znacznej miąższości $(20 \mathrm{~cm})$, która uformowała się po prawdopodobnym pożarze. Ułożyła się na koronie, poniżej pierwotnego poziomu użytkowego II prezbiterium, opadając wyraźnie ku zachodowi. Zachowany układ stratygraficzny dowodzi, że po położeniu fundamentu nastąpiła jakaś destrukcja prezbiterium I, po której w nowo wzniesionym prezbiterium II wymurowano portal boczny w ścianie południowej i wieżyczkę schodową na zachodnim krańcu. Forma prezbiterium I miała pierwszą parę narożnych skarp skośną, a drugą parę ustawioną prostopadle do osi. Dopiero w przebudowie prezbiterium II drugą parę przypór ustawiono ukośnie. Pierwsza bryła prezbiterium była otoczona co najmniej dziesięcioma przyporami, w których dwie narożne były skośne. Wielki fundament po stronie południowej miał prawdopodobnie wspierać jakiś obiekt, znacznie większy i dłuższy niż

${ }^{44}$ Ibid., s. 18. 


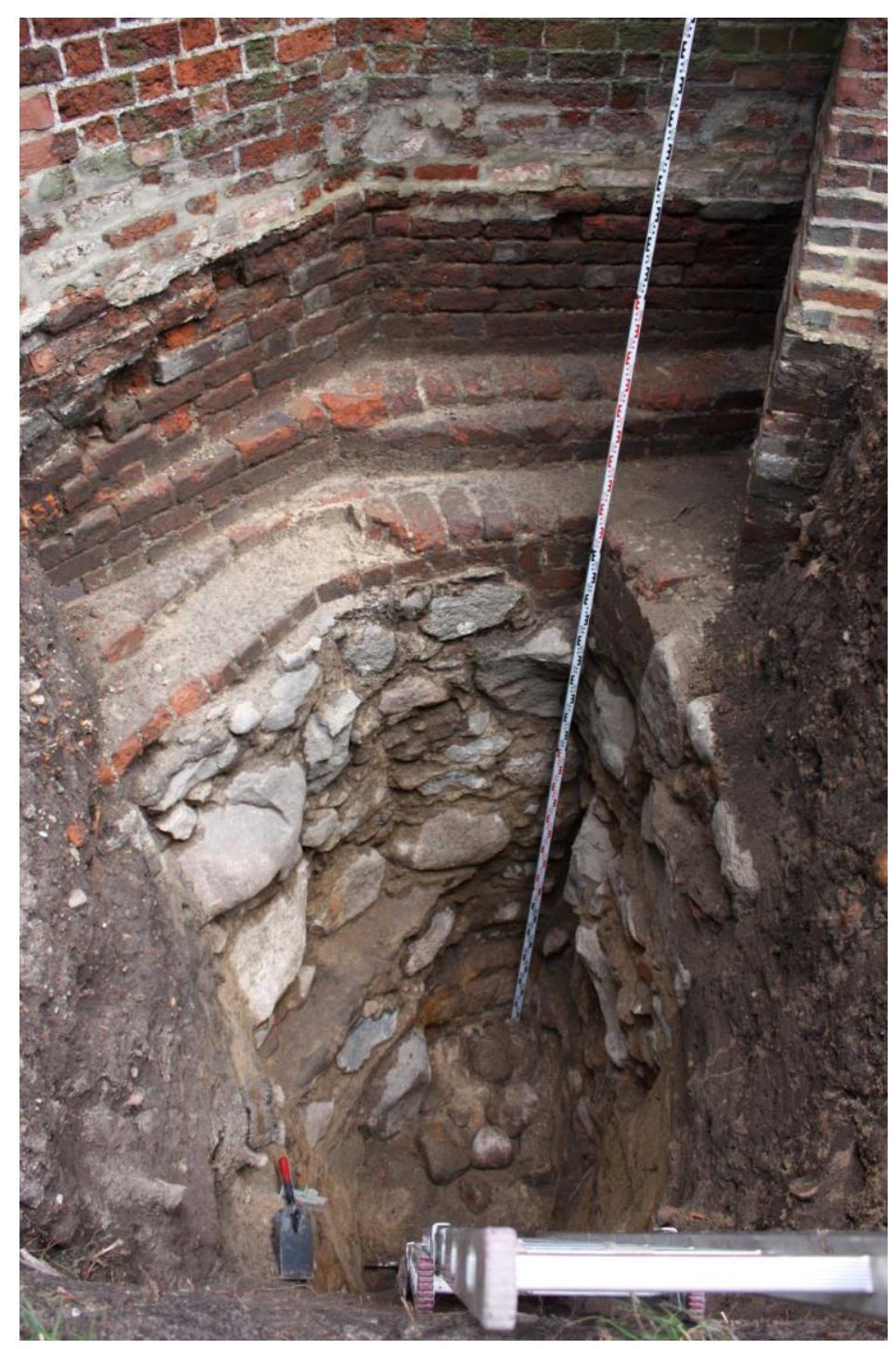

Ryc. 3. Fundamenty północnej strony prezbiterium (wykop W-6/11) (fot. J. Struwe) 
przypora. Na południowej części wielkiego fundamentu, przed portalem bocznym, w 2. połowie XVII w. oparto jeszcze wschodnią ścianę, tzw. łącznika klasztoru. W niektórych partiach bryły prezbiterium możliwe było zaobserwowanie zmiany wątku muru, na przykład: pierwsze siedem rzędów cegieł od odsadzki ułożono w wątku wendyjskim, a powyżej w polskim ${ }^{45}$.

Po badaniach archeologicznych można stwierdzić, że prezbiterium I kościoła św. Jakuba, a raczej pierwszy kościół parafialny Nowego Miasta Torunia, powstał na długo przed rokiem 1309. Okazją do jego budowy mogła być lokacja Nowego Miasta Torunia w 1264 r. Nie ma pewności, jak długo funkcjonowała pierwsza świątynia. Budowa nowej fary była też formą manifestacji władzy i zapisu artystycznych zmian w państwie zakonu krzyżackiego. Dodatkowe pary przypór przy prezbiterium, prócz efektu wieloboczności, mogły wiązać się z założeniem nowego sklepienia ${ }^{46}$.

Kwestią, która w dalszym ciągu czeka na weryfikację, jest dyspozycja wnętrza świątyni św. Jakuba. Aby uzyskać niezbędny ogląd budowli sakralnej jako całości, konieczne są systematyczne badania archeologiczne we wnętrzu kościoła. Bez ich wykonania nie ma możliwości uzyskania całkowitego obrazu problematyki związanej z funkcją i rolą kościoła. Zachowane w świątyni elementy gotyckiego wyposażenia pozwalają na podjęcie próby odzwierciedlenia średniowiecznego pojmowania wiary wśród mieszczan nowomiejskich. Z okresu najstarszego gotyckiego wystroju w świątyni św. Jakuba Apostoła pochodzą głównie malowidła ścienne. Pozostałe dzieła sztuki mają z reguły inną lub niepotwierdzoną proweniencję. Polichromii tych jest w świątyni wiele. Najstarsze $\mathrm{z}$ nich znajdowały się w części zachodniej pod wie$z_{a}{ }^{47}$. Na ich podstawie można odwołać się do średniowiecznego określenia Biblium Pauperum, czyli Biblii dla ubogich. Obrazy miały dawać materialne świadectwo słowom kaznodziei. $Z$ jednej strony były one prostym przesłaniem, jednak z drugiej - źródłem niewyczerpanej symboliki.

\footnotetext{
${ }^{45}$ Ibid., s. 33-35.

${ }^{46}$ K. Sulkowska-Tuszyńska, Toruń - Nowe Miasto 2012, s. 3; tejże, Prezbiterium kościoła św. Jakuba, s. 35.

${ }^{47}$ L. Krantz-Domasłowska, J. Domasłowski, Kościót św. Jakuba, s. 69-70.
} 
Prezbiterium pod względem symbolicznym jest miejscem niezwykłym, wyznacza ono granicę - jest prawdziwym sacrum. W przeciwieństwie do nawy, która odzwierciedla Ziemię i doczesność, prezbiterium jest wyobrażeniem Nieba i dlatego jego forma bywa na ogół bardziej złożona. Prezbiterium często mieści się na podwyższeniu i ma o wiele bogatszy wystrój ${ }^{48}$. W prezbiterium mogą przebywać tylko duchowni, gdyż, jako wybrani przez Boga, pełnią posługę i celebrują Jego poświęcenie ${ }^{49}$. Dokonują tego przy ołtarzu, który stanowi centrum całej budowli. W ogólnym pojęciu ołtarz jest rozumiany jako dowolna powierzchnia, na której składana jest ofiara wotywna. Dla chrześcijan jest symbolem ofiary Jezusa, poprzez śmierć na krzyżu, której dokonał dla wybawienia rodzaju ludzkiego od grzechów ${ }^{50}$. Ołtarz jest najświętszym miejscem w świątyni, powodem jej istnienia, a przede wszystkim samą jej istotą ${ }^{51}$. W kościele katolickim ołtarz główny jest punktem, do którego wszystko zmierza i który wszystko określa ${ }^{52}$. Ołtarz jest kamiennym stołem ofiarnym tej ofiary, która dla upadłej istoty człowieka jest jedynym sposobem nawiązania kontaktu z Bogiem. Ołtarz jest łącznikiem między człowiekiem i Bogiem, jednoczy przyziemność codzienności z doświadczeniem sacrum ${ }^{53}$. Symbolizuje poświęcenie dokonane przez Jezusa dla odkupienia świata z grzechu oraz stanowi pamiątkę Ostatniej Wieczerzy, podczas której Chrystus ustanowił Ofiarę eucharystyczną. W czasie mszy akt ,przeistoczenia” jest dokonywany przez kapłana, a ołtarz jest stołem używanym przy Ostatniej Wieczerzy $^{54}$. Ołtarz swoją szlachetność czerpie ze zgodności ze swoim niebiańskim archetypem, którym jest złoty Ołtarz Jeruzalem niebieskiego, gdzie spoczywa baranek „złożony w ofierze u początków świata" 55 .

\footnotetext{
${ }^{48}$ R. Stemp, op. cit., s. 50.

${ }^{49}$ Ch. Zieliński, Sztuka sakralna: co należy wiedzieć o budowie, urządzeniu, wyposażeniu, ozdobie i konserwacji Domu Bożego: podręcznik opracowany na podstawie przepisów kościelnych, Poznań 1960, s. 47.

${ }^{50}$ R. Stemp, op. cit., s. 60.

${ }^{51}$ J. Hani, op. cit., s. 108.

${ }^{52}$ D. Forstner, Świat symboliki chrześcijańskiej. Leksykon, Warszawa 2001, s. 373.

${ }^{53}$ J. Hani, op. cit., s. 108.

${ }^{54}$ R. Stemp, op. cit., s. 60.

${ }^{55}$ J. Hani, op. cit., s. 108.
} 
Ołtarz nie jest tylko miejscem, w którym składa się najświętszą Ofiarę. Stanowi on centrum większości funkcji liturgicznych. W pobliżu ołtarza dokonują się wszystkie ważniejsze obrzędy poświęcenia ${ }^{56}$.

\section{Podsumowanie}

Badania archeologiczno-architektoniczne przy kościele św. Jakuba Apostoła dostarczyły odpowiedzi na pytania nurtujące wielu badaczy. Wiedza o roli, funkcji i symbolice budowli sakralnych także znacznie się poszerzyła.

Symbol w średniowieczu był rzeczywistością. Współczesny człowiek nie potrafi sobie tego wyobrazić, ale w średniowieczu każdy aspekt życia był związany z tajemnicą. Natura, żywioły, kosmos - każdy z tych elementów był dla ówczesnych ludzi zagadkowy i zadziwiający, a tym samym pełen symboli. Odczytując rzeczywistość, odczytywali język symboli, z którymi tamtejsza codzienność była związana. Świątynia gotycka stanowiła otwartą księgę, która nauczała i łączyła życie codzienne ze światem nadnaturalnym. Budowniczy, tworząc projekt, a następnie go realizując, nie tyle tworzyli budowlę, ile kreowali nowy, ponadnaturalny świat. Styl gotycki najbardziej łączył się z ideą universum, gdyż tworząc coś tak wspaniałego można było wczuć się w rolę Stwórcy.

Kwestia symboliki, zwłaszcza symboliki universum, jest zagadnieniem trudnym i złożonym. Wielu badaczy z różnych dziedzin nauki próbuje przybliżyć jego tajemnicę i funkcję. Zajmują się tym przede wszystkim naukowcy związani ze sztuką, architekturą, religioznawstwem, a zwłaszcza teologią - ale i archeologia jest nauką związaną z tym zagadnieniem. Badania archeologiczno-architektoniczne w kościele św. Jakuba w Toruniu wykazały, że średniowieczna przestrzeń, jej symbolika i funkcja są możliwe do uchwycenia, a tym samym do odtworzenia. Rekonstrukcja przestrzeni sakralnej lub przykościelnej pozwoliła poznać pierwotne założenia świątyni. Jest to istotne, gdyż przestrzeń i bryła kościoła zmieniane były pod wpływem nowych nur-

\footnotetext{
${ }^{56}$ D. Forstner, op. cit., s. 375.
} 
tów. Jej pierwotny wygląd, a tym samym przesłanie zostały zatarte przez czas. Wyniki badań archeologicznych przyniosły nowe spojrzenie na pierwowzory planów architektonicznych, tak jak w przypadku I prezbiterium kościoła św. Jakuba. Archeologia pozwala empirycznie odwołać się do ubiegłych wieków. Za sprawą tej nauki można zbliżyć się do idei i sposobu myślenia ówczesnego społeczeństwa. Dane, które zostały uzyskane podczas badań archeologicznych, mówią bardzo wiele o postrzeganiu świętości. Na podstawie przebadanego obiektu sakralnego można wysunąć tezę, że człowiek średniowiecza był podatny na działanie sacrum, stykał się z nim niemal na każdym kroku swojej ziemskiej wędrówki ku wieczności. Zwłaszcza, że życie codzienne przenikało się z transcendentnym i mistycznym sposobem myślenia.

\section{Bibliografia}

Źródła

Święty Tomasz z Akwinu. Skrót zarysu teologii, oprac. F.W. Bednarski OP, 2000.

Opracowania

Błażejewska A., Pilecka E., Sztuka średniowiecza, [w:] Dzieje sztuki Torunia, pod red. A. Błażejewskiej, Toruń 2009, s. 15-185.

Cicha A., Klasztor cysterek-benedyktynek przy kościele pw. św. Jakuba w Toruniu w świetle źródet ikonograficznych i archeologicznych, [w:] Dzieje i skarby kościoła świętojakubskiego w Toruniu, pod red. K. Kluczwajd, Toruń 2010, s. 141-159.

Eliade M., Inicjacje, obrzędy, stowarzyszenia tajemne: narodziny mistyczne, Kraków 1997.

Eliade M., Traktat o historii religii, Warszawa 2009.

Forstner D., Świat symboliki chrześcijańskiej. Leksykon, Warszawa 2001.

Hani J., Symbolika świątyni chrześcijańskiej, Kraków 1994.

Krantz-Domasłowska L., Dwa miasta - dwa kościoly, [w:] Dzieje i skarby kościoła świętojańskiego w Toruniu, pod red. K. Kluczwajd, M. Woźniaka, Torun 2002, s. 195-218.

Krantz-Domasłowska L., Domasłowski J., Kościót farny w Chetmnie, Toruń 1991.

Krantz-Domasłowska L., Domasłowski J., Kościót św. Jakuba w Toruniu, Toruń 2001. 
Kuczyńska J., Średniowieczne chrzcielnice kamienne w Polsce. Katalog, Lublin 1984.

Lurker M., Przesłanie symboli w mitach, kulturach i religiach, Kraków 1994.

Maier J., Zachować i odnowić wiarę. Rozwinięte $i$ późne średniowiecze, 1000-1499, [w:] Kronika chrześcijańska, pod red. B. Beier, Warszawa 1997, s. 128-213.

Mroczko T., Architektura gotycka na ziemi chetmińskiej, Warszawa 1980.

Stemp R., Sekretny język kościołów i katedr: rozszyfrowywanie świętej symboliki sakralnych budowli chrześcijaństwa, Warszawa 2012.

Sulkowska-Tuszyńska K., Apud terram ante ecclesiam. Nieopisane karty kościoła $i$ parafii św. Jakuba $w$ Toruniu, Pomerania Antiqua, t. XXIII, Gdańsk 2010, s. 249-273.

Sulkowska-Tuszyńska K., Badania archeologiczno-architektoniczne przy kościele św. Jakuba Apostoła w Toruniu 2008, Toruń 2008.

Sulkowska-Tuszyńska K., Kamienna misa chrzcielna odkryta przy kościele św. Jakuba w Toruniu, Slavia Antiqua, t. LIII, 2012, s. 187-204.

Sulkowska-Tuszyńska K., Prezbiterium kościoła św. Jakuba po badaniach archeologiczno-architektonicznych. Nowa historia Nowego Miasta Torunia?, [w:] Nowe Miasto Toruń. 750 lat od lokacji, pod red. K. Mikulskiego, P. Olińskiego, W. Rozynkowskiego, Torun 2014, s. 361-376.

Sulkowska-Tuszyńska K., Primum non nocere! O archeologicznych badaniach wokót toruńskiego kościoła św. Jakuba, [w:] Stare i nowe dziedzictwo Torunia, pod red. A. Raczkowskiego, Toruń 2013, s. 58-73.

Sulkowska-Tuszyńska K., Toruń - Nowe Miasto 2010. Badania archeologicznoarchitektoniczne przy kościele św. Jakuba Apostoła w Toruniu (2 kampania wykopaliskowa), Torun 2011.

Sulkowska-Tuszyńska K., Toruń - Nowe Miasto 2012. Badania archeologicznoarchitektoniczne przy kościele św. Jakuba Apostoła w Toruniu (4 kampania wykopaliskowa), Torun 2013.

Sulkowska-Tuszyńska K., Toruń - Nowe Miasto 2013. Badania archeologicznoarchitektoniczne przy kościele św. Jakuba Apostoła w Toruniu (5 kampania wykopaliskowa), Torun 2014.

Zieliński Ch., Sztuka sakralna: co należy wiedzieć o budowie, urządzeniu, wyposażeniu, ozdobie i konserwacji Domu Bożego: podręcznik opracowany na podstawie przepisów kościelnych, Poznań 1960. 